\title{
Performance of Tomato (Solanum lycopersicum Mill) Cultivars for Quality Production under Protected Cultivation in Subtropics
}

\author{
V. K. Singh ${ }^{1}$, A. K. Bhattacherjee ${ }^{2 *}$, Manoj K. Soni ${ }^{1}$, Anil K. Yadav ${ }^{1}$ and A. Dikshit ${ }^{2}$ \\ ${ }^{1}$ Precision Farming Development Centre (PFDC) and ${ }^{2}$ Division of Post Harvest Management, \\ ICAR-Central Institute for Subtropical Horticulture, Rehmankhera, Lucknow, U.P., India \\ *Corresponding author
}

\section{A B S T R A C T}

\begin{tabular}{|l|}
\hline Ke y w o r d s \\
Tomato, Solanum \\
lycopersicum, \\
Yield, Lycopene, \\
Pectin fractions, \\
Protected \\
cultivation
\end{tabular}

Under the climate change scenario, protected cultivation may possibly provide ample scope for 'off' season production of high value vegetable crops like tomato (Solanum lycopersicum Mill.). The performance of four tomato cultivars (Heemsohna, NS-1218, KSP-1113 and Heemshikhar) in terms of yield and quality parameters under polyhouse (greenhouse) condition was evaluated. The lycopene content and three pectin fractions (water soluble, ammonium oxalate soluble and alkali soluble) of fruits were analyzed by spectrophotometric methods. The total fruit weight/plant varied from $4.16 \mathrm{~kg}$ (KSP-1113) to $18.04 \mathrm{~kg}$ (Heemsohna). The fruit number per plant varied from 114.2-263.0 and individual fruit weight ranged from 18.47-121.12 g. Heemsohna registered higher yield along with maximum marketable shelf life (13 days) as compared to other cultivars. Lycopene content ranged from 2.63 to $5.81 \mathrm{mg} / 100 \mathrm{~g} \mathrm{FW}$ with maximum lycopene in KSP-1113. Though alcohol insoluble solid was maximum (2.36\%) in KSP-1113, water soluble and ammonium oxalate soluble pectin fractions were maximum in Heemsohna (9.02 and $15.76 \mathrm{~g} / 100 \mathrm{~g}$ AIS, respectively) and alkali soluble pectin was maximum in NS1218 (4.72 g/100 g AIS). Heemsohna can be grown in polyhouse for higher yield and overall quality characters and KSP-1113 (cherry tomato) can be grown particularly for higher lycopene content under protected condition in subtropics.

\section{Introduction}

Tomato (Solanum lycopersicum Mill.) is currently the second largest vegetables in India in terms of production. It is consumed in various ways including raw as an ingredient in many dishes and in processed form. Tomato is an outstanding source of many bioactive compounds like lycopene, $\beta$ carotene, phenols, flavonoids and vitamins (Kaur et al., 2013; Shivashankara et al.,
2015). It is one of the richest sources of lycopene, which is a powerful antioxidant helping in decreasing the lipid peroxidation and hydroxyl radical formation by quenching the singlet oxygen (Di Mascio et al., 1989; Shi et al., 2002; Dumas et al., 2003). Epidemiological studies had also indicated positive health benefits by consumption of diets high in lycopene (Matos et al., 2000; Jian et al., 2007). Besides providing disease resistance power to human bodies, vegetables 
can also generate high income and year round employment per unit area. Because of the changing climate scenario due to increase in global mean annual temperature from last century by $0.4-0.7^{\circ} \mathrm{C}$, open cultivation of vegetables is becoming harsher and less economical (IPCC, 2007). This would lead to negative impact on the production of vegetable crops.

Protected structures like polyhouses, tunnels, mulching, etc. can play important role to mitigate the impact of temperature fluctuation, over/under precipitation, fluctuating sun shine hour and infestation of diseases and pests (Singh and Satpathy, 2005; Spaldon et al., 2015). Therefore, cultivation under protected condition has been proved to be more remunerative than open condition. This technology has considerably contributed for improving productivity for areas having adverse weather conditions through slight modification of the natural environment to prolong the harvest period, increase yield, improve quality, enhance the stability of production and make possible round the year production of good quality produce particularly in peri-urban areas. Cultivars with indeterminate growth habit and capacity to produce fruits in 'off' season are found suitable for polyhouse cultivation (Singh et al., 2016).

Though sufficient literature is available on performance of determinate type of tomato cultivars under open field condition, studies on performance of indeterminate type of tomato cultivars under protected condition suited to sub-tropical climate are scanty. The present experiment was, therefore, conducted during the period of 2017-2018 to evaluate the performance of four indeterminate cultivars of tomato having different growth behavior in terms of yield and quality parameters under greenhouse condition.

\section{Materials and Methods}

The experiment was carried out in greenhouse at ICAR-Central Institute for Subtropical Horticulture, Lucknow, India located at latitude $26.55{ }^{\circ} \mathrm{N}$ and longitude $85.59{ }^{\circ} \mathrm{E}$ in the sub-tropical zone of India. Conducive temperature and relative humidity inside greenhouse were maintained in the range of 26-28 ${ }^{\circ} \mathrm{C}$ and $65-90 \%$, respectively (Singh et al., 2015). The experiment was laid out in a randomized block design with three replications. Four indeterminate cultivars of tomato viz. Heemsohna, NS-1218, KSP-1113 (Cherry tomato), and Heemshikhar were considered for evaluation. Seedlings were raised in 98 cups pro-tray with soil less media containing FYM, cocopeat and vermiculite in uniform ratio. Transplanting was done after seedling attained 25 days of age and $20-25 \mathrm{~cm}$ in height during September 2017. Seedlings were transplanted in 15 meter long paired rows spacing $65 \times 45 \mathrm{~cm}$ accommodating 48 plants in each raised bed with three replications for each variety. The recommended cultural practices along with drip irrigation with 2 LPH discharge on alternate days was adapted to provide irrigation at 1-2 liter/plant/day. The indeterminate type plants were regularly trellised and trained to two stem by removing all side shoots/suckers developing. Application of NPK at 250:150:350 in the form of water soluble fertilizers through fertigation at weekly intervals was done.

The total fruit yield per plant, individual fruit weight (average of 100 fruits), fruit number per cluster and fruit number per plant were recorded periodically and pooled. The uniform unblemished tomato fruits having similar size were sampled at red ripe stage for quality analysis. After equilibrating freshly harvested fruit samples to room temperature, ten fruits from three replications of each variety were randomly selected. Fruits were 
washed thoroughly with distilled water to remove dirt and other undesirable particles from the surface and cut into pieces, crushed in a blender and known quantity of homogeneous mass was set apart for quality analysis. Marketable shelf life was assumed on the basis of visual appearance, physiological loss of weight (PLW) and deterioration after storage of 20 fruits of each cultivar at ambient temperature. The PLW of the fruits was calculated as cumulative per cent loss in weight based on the initial fruit weight and loss in weight recorded by sampling daily. Peel thickness was calculated with micrometer $(0-25 \times 0.01 \mathrm{~mm})$.

The total soluble solid (TSS) was determined by digital hand held refractometer (Model PAL-1, Atago Co. Ltd., Japan) with a range of 0 to $53{ }^{\circ}$ Brix by placing 1 to 2 drops of clear juice on the prism. Acidity was estimated by titration of the tomato extract against $0.1 \mathrm{~N} \mathrm{NaOH}$ using phenolphthalein indicator and expressed in per cent using citric acid as equivalent (AOAC, 2000). TSS/acidity ratio was calculated by dividing total soluble solid to titratable acidity of the given sample under analysis. Total lycopene content of the homogenized fruits was analyzed by spectrophotometric method (Lichtenthaler, 1987) and results were expressed as mg/100 $\mathrm{g}$ fresh weight (FW). After estimation by soxhlet extraction, alcohol insoluble solids (AIS) was characterized into three pectin fractions using distilled water, $0.05 \mathrm{M}$ ammonium oxalate and $0.05 \mathrm{M}$ sodium hydroxide by subsequent extraction as per the method described by Roe and Bruemmer (1981). Pectin fractions were estimated colorimetrically by adding $1.0 \mathrm{ml}$ of carbazole reagent $(0.1 \%$ in absolute alcohol $)$ and $12.0 \mathrm{ml}$ of concentrated sulfuric acid to $2.0 \mathrm{ml}$ of pectin solution with constant agitation. The tubes were closed with rubber stoppers, allowed to stand for $10 \mathrm{~min}$ and colour was read at $525 \mathrm{~nm}$ in a double beam
UV-VIS spectrophotometer (Labomed Inc., USA). Blank sample was prepared by adding $1 \mathrm{ml}$ of purified alcohol instead of $1 \mathrm{ml}$ carbazole in the reaction mixture. Standard was made by using galacturonic acid (100 $\mu \mathrm{g} / \mathrm{ml})$.

The statistical data was analyzed using scientific data analysis and graphing software Sigma Plot 12 Systat Software Inc., San Jose, California, USA and Web Agri Stat Package (WASP) version 2.0 developed at ICAR Research Complex for Goa, Goa, India following completely randomized design.

\section{Results and Discussion}

\section{Fruit physical parameters}

Average fruit yield per plant and its attributes viz., number of fruits per plant, fruit number per bunch, individual fruit weight and marketable shelf life of four tomato cultivars are presented in Table 1. The average fruit yield per plant ranged from 4.16 to $18.04 \mathrm{~kg}$ with maximum in Heemsohna (18.04 kg) followed by Heemshikhar (17.48 kg) and minimum in KSP-1113 (4.16 kg). Weekly performance of four cultivars in terms of yield from $2^{\text {nd }}$ week of March to $1^{\text {st }}$ week of June, 2017 has been shown in Table 2. Fruit number per plant in KSP-1113 was maximum (263 fruits) as compared to other cultivars which ranged from 114.2 - 153.2 fruit per plant, wherein minimum number of fruit (114.2 fruit per plant) was recorded in NS1218. Amongst the cultivars, KSP-1113 (Cherry tomato) registered highest number of fruits (21.4) per cluster and lowest (5) was in NS-1218. On the other hand, KSP-1113 had lowest $(18.50 \mathrm{~g})$ individual fruit weight as compared to the rest of the cultivars which ranged from $86.76-121.12 \mathrm{~g}$ with highest individual fruit weight was in Heemsohna (Table 1). Variation in yield and contributing parameters may be due to their different 
genetic characteristics. Among the cultivars, Heemsohna exhibited maximum marketable shelf life (13.2 days) and KSP-1113 the minimum (5 days) based on visual appearance. The perusal of data on physiological weight loss (PLW) clearly indicated that Heemsohna had low PLW (7.1,
8.7 and $10.9 \%)$ for the fruits harvested during different months (Fig. 1) with highest marketable shelf life (13.2 days) followed by Heemshikhar (12.0 days). On the other hand, KSP-1113 registered maximum PLW (16.8, 15.2 and $14.4 \%$ ) with lowest marketable shelf life (5 days).

Table.1 Yield parameters and shelf life of different indeterminate cultivars of tomato

\begin{tabular}{|c|c|c|c|c|c|c|}
\hline Cultivar & $\begin{array}{l}\text { Total no. } \\
\text { of fruits } \\
\text { per plant* }\end{array}$ & $\begin{array}{l}\text { No. of } \\
\text { fruits } \\
\text { per } \\
\text { cluster* }\end{array}$ & $\begin{array}{c}\text { Individua } \\
\text { I fruit } \\
\text { weight } \\
\text { (g) } * *\end{array}$ & $\begin{array}{l}\text { Total fruit } \\
\text { weight (kg/ } \\
\text { plant) }\end{array}$ & $\begin{array}{c}\text { Peel } \\
\text { thickness } \\
\text { of ripe fruit } \\
\text { (mm) }\end{array}$ & $\begin{array}{l}\text { Marketable } \\
\text { Shelf Life } \\
\text { (Days)*** }\end{array}$ \\
\hline Heemsohna & $153.24^{\mathrm{b}}$ & $7.80^{\mathbf{b}}$ & $121.12^{\mathrm{a}}$ & $18.04^{\mathrm{a}}$ & $0.75^{\mathrm{a}}$ & $13.2^{\mathrm{a}}$ \\
\hline NS-1218 & $114.27^{\mathrm{c}}$ & $5.00^{\mathrm{c}}$ & $86.76^{b}$ & $9.53^{\mathrm{b}}$ & $0.65^{\mathrm{ab}}$ & $7.4^{b}$ \\
\hline KSP-1113 & $263.01^{\mathrm{a}}$ & $21.43^{\mathrm{a}}$ & $18.50^{c}$ & $4.16^{c}$ & $0.37^{\mathbf{c}}$ & $5.0^{\mathbf{c}}$ \\
\hline Heemshikha & $149.80^{\mathrm{b}}$ & $7.20^{\mathrm{bc}}$ & $118.29^{\mathrm{a}}$ & $17.48^{\mathrm{a}}$ & $0.50^{\mathrm{bc}}$ & $12.0^{\mathrm{a}}$ \\
\hline LSD at 5\% & 8.706 & 1.80 & 7.666 & 0.98 & 0.154 & 1.551 \\
\hline
\end{tabular}

*Average of 20 plants/bunch, **Average of 20 fruits, ***Average of 20 fruits based on visual appearance, Data with same number in column as superscript are statistically non-significant

Table.2 Yield of different cultivars of tomato during different periods

\begin{tabular}{|l|l|l|l|l|l|l|l|l|l|l|}
\hline Cultivar & \multicolumn{9}{|c|}{ Yield (kg/plant) } \\
\cline { 2 - 13 } & $\begin{array}{l}\text { March } \\
2^{\text {nd }}\end{array}$ & $\begin{array}{l}\text { March } \\
3^{\text {rd }}\end{array}$ & $\begin{array}{l}\text { March } \\
5^{\text {th }}\end{array}$ & $\begin{array}{l}\text { April } \\
1^{\text {st }}\end{array}$ & $\begin{array}{l}\text { April } \\
3^{\text {rd }}\end{array}$ & $\begin{array}{l}\text { April } \\
4^{\text {th }}\end{array}$ & $\begin{array}{l}\text { May } \\
2^{\text {nd }}\end{array}$ & $\begin{array}{l}\text { May } \\
3^{\text {rd }}\end{array}$ & $\begin{array}{l}\text { May } \\
4^{\text {th }}\end{array}$ & $\begin{array}{l}\text { June } \\
1^{\text {st }}\end{array}$ \\
& Week & Week & Week & Week & Week & Week & Week & Week & Week & Week \\
\hline Heemsohna & 1.924 & 2.32 & 2.251 & 2.178 & 2.173 & 2.112 & 1.804 & 1.702 & 0.898 & 0.673 \\
\hline NS-1218 & 1.32 & 0.886 & 1.400 & 1.31 & 0.76 & 1.064 & 0.923 & 0.384 & 0.842 & 0.662 \\
\hline KSP-1113 & 0.76 & 0.38 & 0.412 & 0.362 & 0.304 & 0.374 & 0.435 & 0.59 & 0.314 & 0.224 \\
\hline Heemshikhar & 2.542 & 1.782 & 2.354 & 1.906 & 2.17 & 1.88 & 1.332 & 1.836 & 0.998 & 0.684 \\
\hline
\end{tabular}

Table. 3 Chemical parameters of four tomato cultivars

\begin{tabular}{|l|c|c|c|c|}
\hline Cultivar & TSS $\left({ }^{\mathbf{0}}\right.$ Brix $)$ & Acidity $(\boldsymbol{\%})$ & TSS/Acidity ratio & AIS* $^{*}(\mathbf{\%})$ \\
\hline Heemsohna & $4.10^{\mathbf{b}}$ & 0.50 & $8.18^{\mathbf{b}}$ & $1.77^{\mathbf{b}}$ \\
\hline NS-1218 & $4.08^{\mathbf{b}}$ & 0.61 & $6.69^{\mathbf{c}}$ & $1.35^{\mathbf{c}}$ \\
\hline KSP-1113 & $8.28^{\mathbf{a}}$ & 0.62 & $13.29^{\mathbf{a}}$ & $2.36^{\mathbf{a}}$ \\
\hline Heemshikhar & $4.03^{\mathbf{b}}$ & 0.53 & $7.66^{\mathbf{b c}}$ & $2.11^{\mathbf{a}}$ \\
\hline LSD at 5\% & 0.248 & NS & 1.06 & 0.308 \\
\hline
\end{tabular}

*AIS = Alcohol insoluble solids, Data with same number in column as superscript are statistically non-significant 
Fig.1 Physiological loss in weight (\%) for four tomato cultivars at different harvesting period (average of 20 fruits based on weight loss)

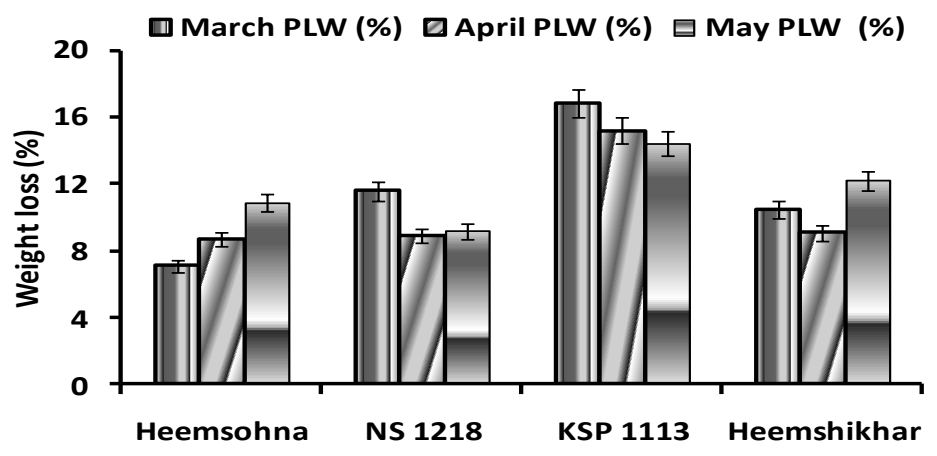

Fig. 2 Variations in (a) lycopene content (LSD at 5\% $=0.212$ ) and (b) pectin content [WE = water soluble $(\mathrm{LSD}$ at $5 \%=0.701), \mathrm{AOE}=$ Ammonium oxalate soluble $(\mathrm{LSD}$ at $5 \%=1.053)$ and $\mathrm{AE}=$ Alkali soluble $(\mathrm{LSD}$ at $5 \%=0.829)]$ of four tomato cultivars
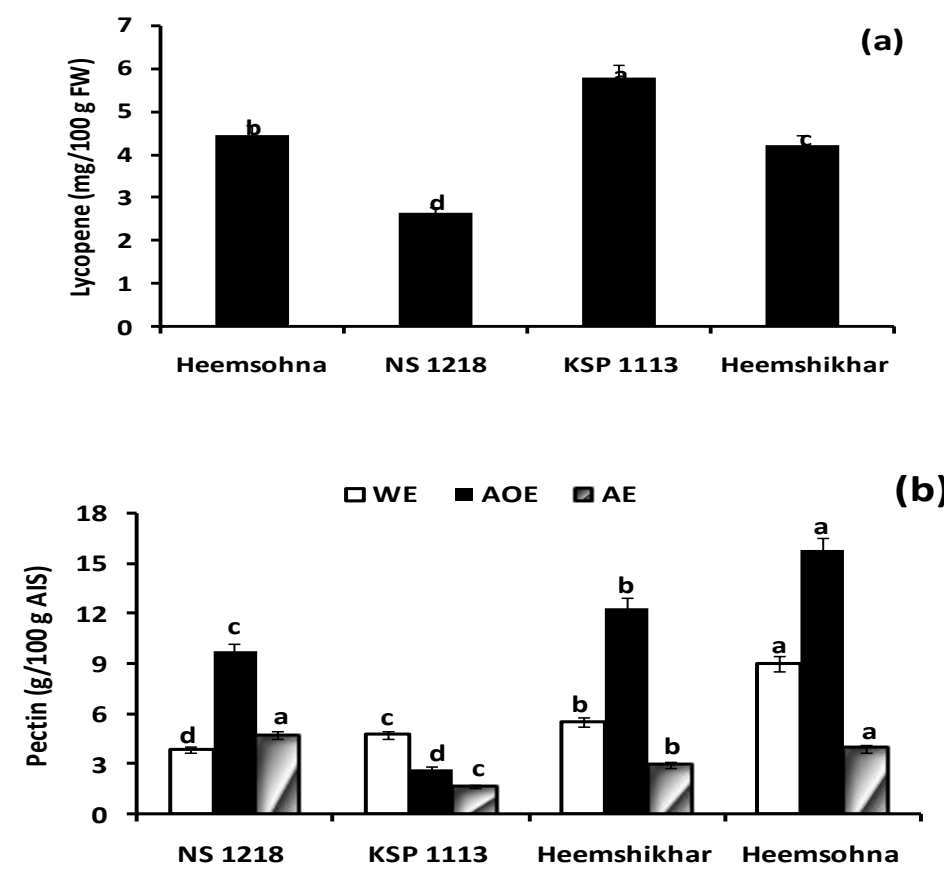

\section{Fruit chemical parameters}

TSS, acidity and their ratio are key determinant of shelf life and quality of the crops, whether it is for the fresh produce or for processing. At red ripe stage, TSS ranged from $4.03{ }^{\circ} \mathrm{B}$ in Heemshikhar to $8.27{ }^{\circ} \mathrm{B}$ in $\mathrm{KSP}-1113$ and the acidity in cultivars ranged between 0.50 and 0.62 per cent which is desirable traits for shelf life and processing of tomato (Table 3). TSS/acidity ratio was in the range of 6.69 to 13.29 being maximum in KSP-1113 and minimum in NS-1218. Peel thickness in four cultivars ranged from 0.75 $0.37 \mathrm{~mm}$. Higher thickness $(0.75 \mathrm{~mm})$ of peel and lower TSS in Heemsohna may be one of the reasons for the higher shelf life as compared to lower shelf life with higher TSS 
and lower peel thickness $(0.37 \mathrm{~mm})$ in KSP1113. The lycopene content varied among the cultivars in the range of 2.63 to $5.81 \mathrm{mg} / 100 \mathrm{~g}$ FW. Cherry tomato cv. KSP-1113 exhibited maximum lycopene content $(5.81 \mathrm{mg} / 100 \mathrm{~g}$ $\mathrm{FW})$ and minimum in NS-1218 (2.63 mg/100 g FW) (Fig. 2a). The pectin content in red ripe tomato fruit was estimated. AIS content was recorded maximum in KSP-1113 $(2.36 \%)$ and minimum in NS-1218 $(1.35 \%)$. The recovery of water soluble and ammonium oxalate soluble pectin was maximum in Heemsohna (9.02 and $15.76 \mathrm{~g} / 100 \mathrm{~g}$ AIS), however, NS1218 contained maximum amount of alkali soluble pectin (4.72 g/100 g AIS) (Fig. 2b). Interestingly, the pulp of KSP-1113 contains maximum level of alcohol insoluble solids $(2.36 \%)$ and minimum in NS-1218 (1.35\%).

The parameters of economic importance like fruit weight and yield are better under protected conditions compared to open field conditions (Rana et al., 2014). Tomato fruit yield under greenhouse condition may reach 5.7 to $6.0 \mathrm{~kg} /$ plant while under open field condition 1.4 to $2.0 \mathrm{~kg} /$ plant can be achieved under favourable climatic condition (Singh et al., 2015). TSS and acidity ratio can contribute strongly to the tomato shelf life and consistency (Carrari and Fernie, 2006). TSS/acidity ratio has also been reported as one of the important components in tomato fruit flavour and storage stability (George et al., 2004). Visible fruit colour of tomato is one the most important visual quality parameters for consumers as it imparts attractive red colour due to predominant constituent pigment, lycopene. There are several important factors that affect the fruit quality and lycopene content in tomato viz., light and temperature, besides other cultural practices. Wide variations in lycopene content (3.0 to $11.0 \mathrm{mg} / 100 \mathrm{~g}$ ) have been reported in Hungarian, Spanish and Indian tomatoes (Adalid et al., 2010). Cherry tomatoes have also contained higher content of lycopene than local cultivars which were grown under open conditions (Raffo et al., 2006). Differences between small, high pigmented cherry tomato and other normal size cultivars have been attributed to genotypic factors triggering enhanced enzymatic activity of phytoene synthase-I that causes a massive production of lycopene precursors. Fraser et al., (2009) reported that reduced cycling rate of this molecule to synthesize carotenes resulted in higher accumulation of lycopene during ripening. Another plausible explanation accounting for significant differences between the cherry tomato and other cultivars is related to their smaller fruit size and high peel percentage. All the cultivars were normal sized $(86.76-121.12$ g) with low peel percentage; on the other hand the cherry tomato, which was smaller sized fruits $(18.50 \mathrm{~g})$, had higher peel percentage (data not shown). As peel is the main reservoir of lycopene and accumulates 3-4 times higher content, small sized cherry tomato tends to have higher lycopene content than the bigger sized fruits of other cultivars. This adequately explains highest lycopene content observed in KSP-1113 in comparison to other three cultivars. Similar observations were recorded in small sized Corbarini and Campari cultivars (Toor and Savage, 2005). Genotype influenced the lycopene content of fruit which varied from $6.95 \mathrm{mg} / 100 \mathrm{~g}$ fresh fruit (Carmem) to $8.88 \mathrm{mg} / 100 \mathrm{~g}$ fresh fruit (BGH-320) (Caliman et al., 2010). Apart from genotypic factors, environmental factors such as temperature and sunlight can also considerably affect the biosynthesis of lycopene in tomato. Under high-tech greenhouse condition, the optimum temperature $\left(26-28{ }^{\circ} \mathrm{C}\right)$, relative humidity (65-85\%) for lycopene synthesis as well as partial shading to reduce the surface temperature help in minimizing lycopene degradation (Zoltán et al., 2013). The work on lycopene biosynthesis under tropical conditions was also reported by Kaur et al., 
(2013). The authors reported that optimum temperature range for biosynthesis of lycopene is between 12 to $32{ }^{\circ} \mathrm{C}$. In subtropics during May-June, temperature shoots up above $32{ }^{\circ} \mathrm{C}$ and can reach beyond $40{ }^{\circ} \mathrm{C}$. This coupled with excessive sunlight hinders lycopene synthesis in tomato. The AIS content was found significantly low in all cultivars at red ripe stage. Lower AIS upon ripening was also reported in other fruit crops like mango (Tandon and Kalra, 1984) where the authors mentioned that sharp decline in starch content could be the reason for fall of AIS. The solubilization of pectic substances during ripening by various enzymes might be the reason for decrease in AIS. This result was well supported by Jagtiani et al., (1988) in papaya fruit where the activity of pectin methyl esterase increased and more pectin was solubilized during ripening of papaya fruit. Earlier literatures supported that water soluble (high methoxyl) and ammonium oxalate soluble (low methoxyl) pectin increased while alkali soluble pectin (protopectin) decreased at the time of ripening in many horticultural crops viz., mango (Tandon and Kalra, 1984), guava (Killadi et al., 2018), sweet cherry (Fils-Lycaon and Buret, 1990) and bael (Anup et al., 2017), which is evident in the present study. All the authors opined that the initiation of solubilization of pectin by some enzymes caused the increase in WE and AOE contents and decrease in $\mathrm{AE}$ content during ripening of fruits. Thus, Heemsohna was found better in terms of high amount of water soluble pectin.

Based on different attributes recorded, it can be concluded that tomato cultivars grown under greenhouse condition offers an opportunity to improve the quality and extended availability period in subtropical regions. On the basis of higher yield, better marketable shelf life and higher pectin content, cultivar Heemsohna and on the basis of higher lycopene content, cultivar KSP-
1113 can be recommended for cultivation under protected condition even at higher temperature in subtropics.

\section{Acknowledgements}

This study was supported from the Department of Agriculture and Co-operation, Ministry of Agriculture and Farmers' Welfare, NCPAH, Government of India, New Delhi vide grant no. F. No. 18-33/2017MIDH dated 26/09/2017.

\section{References}

Adalid A M, Roselló S and Nuez F. 2010. Evaluation and selection of tomato accessions (Solanum lycopersicon) for content of lycopene, $\beta$-carotene and ascorbic acid. Journal of Food Composition and Analysis 23:613618. doi:10.1016/j.jfca.2010.03.001

Anup K B, Dikshit A and Dileep K T. 2017. Pectin transitions during growth and development of bael (Aegle marmelos (L.) Correa) fruit. Analytical Chemistry: An Indian Journal 17:119.

[AOAC] Association of Official Analytical Chemists. 2000. Official Methods of Analysis. An AOAC Publication, Maryland, USA.

Caliman F R B, da Silva D J H, Stringheta P C, Fontes P C R, Moreira G R and Mantovani E C. 2010. Quality of tomatoes grown under a protected environment and field conditions. IDESIA (Chile) 28:75-82.

Carrari F and Fernie A R. 2006. Metabolic regulation underlying tomato fruit development. Journal of Experimental Botany 57:1883-1897. https://doi.org/10.1093/jxb/erj020

Di Mascio P, Kaiser S and Sies H. 1989. Lycopene as the most effective biological carotenoid singlet oxygen quencher. Archives of Biochemistry 
and Biophysics 274:532-538. https://doi.org/10.1016/0003-

9861(89)90467-0

Dumas Y, Dadomo M, Lucca G D and Grolier P. 2003. Effects of environmental factors and agricultural techniques on antioxidant content of tomatoes. Journal of the Science of Food and Agriculture 83:369-382. https://doi.org/10.1002/jsfa.1370

Fils-Lycaon B and Buret M. 1990. Loss of firmness and changes in pectic fractions during ripening and over ripening of sweet cherry. Hort. Science 25:777-778. https://doi.org/10.21273/HORTSCI.25 .7 .777

Fraser P D, Enfissi E M A and Bramley P M. 2009. Genetic engineering of carotenoid formation in tomato fruit and the potential application of systems and synthetic biology approaches. Archives of Biochemistry and Biophysics 483:196-204. https://doi.org/10.1016/j.abb.2008.10. 009

George B, Kaur C, Khurdiya D S and Kapoor H C. 2004. Antioxidants in tomato (Lycopersium esculentum) as a function of genotype. Food Chemistry 84:45-51. doi:10.1016/S03088146(03)00165-1

[IPCC] Intergovernmental Panel on Climate Change 2007. Climate change 2007: The physical science basis. Contribution of Working Group I to the Fourth Assessment Report of the IPCC, $\mathrm{p}$ 996. Solomon S, Qin D, Manning $\mathrm{M}$, Chen $\mathrm{Z}$, Marquis $\mathrm{M}$, Averyt K B, Tignor M and Miller H L (Eds). A Cambridge University Press Publication, Cambridge, UK.

Jagtiani J, Chan Jr H T and Sakai W S. 1988. Tropical fruit processing. An Academic Press Publication, New York.
Jian L, Lee A H and Binns C W. 2007. Tea and lycopene protect against prostate cancer. Asia Pacific Journal of Clinical Nutrition 16:453-457.

Kaur C, Walia S, Nagal S, Walia S, Singh J, Singh B B, Saha S, Singh B, Kalia P, Jaggi $S$ and Sarika 2013. Functional quality and antioxidant composition of selected tomato (Solanum lycopersicon L) cultivars grown in Northern India. LWT-Food Science and Technology 50:139-145. http://dx.doi.org/10.1016/j.lwt.2012.0 6.013

Killadi B, Chaurasia R and Shukla D K. 2018. Pectin fractions in guava (Psidium guajava L.) cultivars 'Shweta' and 'Lalit'. International Journal of Chemical Studies 6:1114-1117.

Lichtenthaler H K. 1987. Chlorophylls and carotenoids: pigments of photosynthetic biomembranes. Methods in Enzymology 148:350-382.

Matos H R, Di Mascio P and Medeiros M H G. 2000. Protective effect of lycopene on lipid peroxidation and oxidative DNA damage in cell culture. Archives of Biochemistry and Biophysics 383:56-59. https://doi.org/10.1006/ abbi.2000.2035

Raffo A, La Malfa G, Fogliano V, Maiani G and Quaglia G. 2006. Seasonal variations in antioxidant components of cherry tomatoes (Lycopersicon esculentum cv. Naomi F1). Journal of Food Composition and Analysis 19:11-19. doi:10.1016/j.jfca.2005. 02.003

Rana N, Kumar M, Walia A and Sharma S. 2014. Tomato fruit quality under protected environment and open field conditions. International Journal of Bio-resource and Stress Management 5:422-426. DOI: $10.5958 / 0976-$ 4038.2014.00592.2 
Roe B and Bruemmer J H. 1981. Changes in pectic substances and enzymes during ripening and storage of 'Keitt' mangoes. Journal of Food Science 46:186-189.

Shi J, Maguer Le M and Bryan M. 2002. Lycopene from tomatoes. Funtional Foods. Biochemical and Processing Aspects, vol. 2, pp 135-166. Shi J and Ghazza Le M M (Eds). A CRC Press Publication, Ottawa, Canada.

Shivashankara K S, Pavithra K C, Laxman R $\mathrm{H}$, Sadashiva A T, Roy $\mathrm{T}$ K and Geetha G A. 2015. Changes in fruit quality and carotenoid profile in tomato (Solanum lycopersicum L.) genotypes under elevated temperature. Journal of Horticultural Sciences 10:38-43.

Singh R K and Satpathy K K. 2005. Scope and adoption of plastic culture technologies in north eastern hill region. Agricultural Mechanization in North East India, pp 114-121. An ICAR Research Complex for NEH Region Publication, Barapani, Meghalaya, India.

Singh V K, Rajan S, Singh A and Soni M K. 2015. Protected Cultivation of Horticultural Crops, Technical Bulletin no. 1, pp 4-7. An ICARCentral Institute for Subtropical Horticulture Publication, Lucknow,
India.

Singh V K, Singh K and Saxena P. 2016. Lycopene estimates in terms of chromaticity value in tomato (Solanum lycopersicum Mill.). Indian Journal of Agricultural Sciences 86:1225-1227.

Spaldon S, Samnotra R K and Chopra S. 2015. Climate resilient technologies to meet the challenges in vegetable production. International Journal of Current Research and Academic Review 3(2):28-47.

Tandon D K and Kalra S K. 1984. Pectin changes during the development of mango fruit cv. Dashehari. Journal of Horticultural Science 59:283-286.

Toor R K and Savage G P. 2005. Antioxidant activities in different fractions of tomato. Food Research International 38:487-494. doi:10.1016/j.foodres.2004.10.016

Zoltán P, Szuvandzsiev P, Nemenyi A, Helyes L and Lugasi A. 2011. The effect of natural light on changes in antioxidant content and color parameters of vine-ripened tomato (Solanum lycopersicum L.) fruits. HortScience 46(4):583-585. https://doi.org/10.21273/HORTSCI.4. 4.583 .

\section{How to cite this article:}

Singh, V. K., A. K. Bhattacherjee, Manoj K. Soni, Anil K. Yadav and Dikshit, A. 2020. Performance of Tomato (Solanum lycopersicum Mill) Cultivars for Quality Production under Protected Cultivation in Subtropics. Int.J.Curr.Microbiol.App.Sci. 9(11): 1127-1135. doi: https://doi.org/10.20546/ijcmas.2020.911.131 